Article

\title{
Goat Milk with Different Alpha-s1 Casein Genotype (CSN1S1) Fermented by Selected Lactobacillus paracasei as Potential Functional Food
}

\author{
Nicoletta P. Mangia ${ }^{1, *}$, Leacady Saliba ${ }^{1}\left(\mathbb{D}\right.$, Georgia Zoumpopoulou ${ }^{2}$, Stefania Chessa ${ }^{3,4}$, \\ Rania Anastasiou ${ }^{2}$, Ioannis Karayiannis ${ }^{5}$, Dionyssios Sgouras ${ }^{5}$ (D) Effie Tsakalidou ${ }^{2}$ and \\ Anna Nudda ${ }^{1}$ \\ 1 Dipartimento di Agraria, Università degli Studi di Sassari, 07100 Sassari, Italy \\ 2 Laboratory of Dairy Research, Department of Food Science and Human Nutrition, Agricultural University of \\ Athens, 11521 Athens, Greece \\ 3 Istituto di Biologia e Biotecnologia Agraria, CNR, 26900 Lodi, Italy \\ 4 Dipartimento di Scienze Veterinarie, Università degli Studi di Torino, Grugliasco, 10095 Turin, Italy \\ 5 Laboratory of Medical Microbiology, Hellenic Pasteur Institute, 11521 Athens, Greece \\ * Correspondence: nmangia@uniss.it; Tel.: +39-079-229287
}

Received: 29 April 2019; Accepted: 27 June 2019; Published: 1 July 2019

\begin{abstract}
The characteristics of fermented milk are affected by the type of milk used and the microorganisms involved in the fermentation process. Goat milk has been widely suggested as a possible alternative to cow milk in allergic subjects, because of the high genetic variability in alpha-s1 casein (CSN1S1) content, which is associated with different technological and nutritional properties of milk. The aim of the study was to evaluate the suitability of goat milk with low and high CSN1S1 to produce fermented milk. In addition, the performance as starter of selected Lactobacillus paracasei FS109 strain compared to no-selected L. paracasei strains was investigated. Initially, the selected L. paracasei FS109 strain was tested for adhesion ability to HT-29 and Caco-2 cells and immunomodulation effect. Then, the strain was used to produce fermented milk from goat milk with a low and high casein CSN1S1 genotype. The results indicated that greater acidifying activity was obtained for L. paracasei FS109 after $24 \mathrm{~h}$ of fermentation than the other two strains tested independently by the CSN1S1 genotype. L. paracasei FS109 grew well during fermentation, reaching a higher value (>8.5 $\log \mathrm{CFU} / \mathrm{mL})$. Interestingly, the same strain maintained a high viable population (about $9 \log \mathrm{CFU} / \mathrm{mL}$ ) during the 30-day cold storage of the product. The present study shows for the first time the suitability of the goat milk with low CSN1S1 genotypes to produce fermented milk and highlight the importance of strain selection in determination of technological and beneficial traits. Combining goat milk with low CSN1S1 and selected strains could be a strategy of improving traditional and functional fermented milk market.
\end{abstract}

Keywords: Lactobacillus paracasei; immunomodulation; goat milk; casein genotype; fermented milk; functional food

\section{Introduction}

Fermented milk enhances sensorial and nutritional features when compared to the raw material and has always been perceived by consumers as a health food. These later traits are related to the type of milk used, the microorganisms involved, and the technology applied. Goat milk is widely used in many countries as an alternative to cow milk, especially for children showing cow milk intolerance (MCI) or cow milk allergy (CMA) [1]. Caseins (CN), and in particular alpha s-CN, are the major milk allergens [2]. Caseins are encoded by four well-known genes and characterized in goats by a 
high genetic variability. Considering all variants described in the literature, CSN1S1, encoding for $\alpha \mathrm{S} 1$-casein, is characterized by at least 23 variants (A, A2, A3, A', B1, B2, B3, B4, B', C, D, D1, E, F, G, H, I, L, M, N, 01, 02, and 04) as described by Chessa and Caroli [3]. Although on average, $\alpha$ S1-casein represents only the $10-13 \%$ of the total casein content in goat milk, the respective genes are the most studied because, depending on the genetic variant, the synthesis level of this casein varies greatly: The strong alleles (A, A2, A3, A', B1, B2, B3, B4, B', C, H, L, and M) produce about $3.5 \mathrm{~g} / \mathrm{L}$ of $\alpha$ S1-casein each, the intermediate alleles (D1, E, and I) produce 1.1-1.8 g/L, the weak alleles (D, F, and G) $0.45-0.6$ $\mathrm{g} / \mathrm{L}$, and the null alleles $(01,02,04$, and $\mathrm{N})$ produce no $\alpha$ S1-casein $[4,5]$.

The presence of particular $\alpha$ S1-variants can affect the composition and technological features of goat fermented milk. Perna et al. [6] reported the lowest phenolic compounds content in the yogurt from goats with weak alleles at CSN1S1 loci (FF) compared with yogurt from goats with strong alleles at CSN1S1 loci (AA, BB, AB). A study conducted on Norwegian goat breed shown as milk with high S1-CN evidenced a higher coagulant activity than milk with a weak $\alpha$ S1-CN [7]. The different nutritional value of milk from animals with a different CSN1S1 genotype has been evidenced by several studies. In guinea pigs, the anti-goat beta- $\lg \operatorname{IgG1}$ antibodies and intestinal anaphylaxis were significantly decreased when animals were fed with goat milk with low $(0.7 \mathrm{~g} / \mathrm{L})$ CSN1S1 content compared with those fed with milk with high $(7 \mathrm{~g} / \mathrm{L})$ CSN1S1 [8]. Albenzio et al. [9] showed a lower production of pro-inflammatory cytokines (IL6, IL8 and TNF) from cultured peripheral blood mononuclear cells from infants with cow milk protein allergy after exposure to goat milk casein than after exposure to cow milk.

Currently, the high nutritional and therapeutic potential of caprine milk fermented with selected lactic acid bacteria (LAB) with functional features has been accentuated [10-12], as well as the opportunity to set up innovative products supplemented and/or fortified with different ingredients [13]. However, the counts of probiotic microorganisms in such food products decrease during cold storage, thus reducing or compromising the health value of the fermented milk. This is due to several factors, such as low pH, production of lactic and acetic acid [14] as well as storage conditions. In a previous study carried out by our research group, several autochthonous Lactobacillus (L.) paracasei strains showed interesting attributes, such as good survival in gastric and intestinal juice models, inhibition of undesirable bacteria growth, and susceptibility towards antibiotics, such as chloramphenicol, clindamycin, penicillin, amoxicillin, erythromycin, tetracycline, and ampicillin [15].

In the present study, we deepened some probiotic aspects, such as the adhesion ability of $L$. paracasei FS109 strain, as well as their immunomodulatory potential. Adhesion prolongs transition of bacteria though the gut, thus enhancing their health impact through antagonistic activities against enteropathogens [16] and stimulation of the immune responses [17], with those referring to upregulation of anti-inflammatory cytokines, such as Interleukin 10 (IL10) [18], reducing nitrite to nitric oxide [19], and downregulating the cyclooxygenase-2 (COX2) expression [20,21], being the most promising ones.

The objective of the present study was to evaluate the suitability of goat milk with low CSN1S1 to produce fermented milk. In addition, the ability of selected L. paracasei strain as a starter to produce fermented milk from low CSN1S1 milk has been also investigated.

\section{Materials and Methods}

\subsection{Milk Samples Selection}

The study was conducted at a private farm located in the northwest of Sardinia, Italy. Details on this study were reported by Caboni et al. [22]. Briefly, 14 goats were selected on the basis of the CSN1S1 genotype previously typed and divided into two groups: one group of 7 goats, including animals classified as heterozygous for weak or null alleles (low group; LCsM; goats with FF, 0101, and F01 genotype), and one group of 7 goats with strong homozygous genotypes (high group; HCsM; goats with AA genotype). Animals were kept on pens and milked twice a day (h 7:00 and 17:00). Each group of animals was fed alfalfa hay (on average $1.1 \mathrm{~kg} /$ day per goat, as fed), split into 2 feedings (morning 
and evening), and each animal was individually fed a commercial concentrate $(0.6 \mathrm{~kg} /$ day per goat, as fed) during both milkings, and beet pulp $(0.11 \mathrm{~kg} /$ day per goat, as fed $)$. Goats grazed on natural pasture during approximately $3 \mathrm{~h}$ after the morning milking every day. Pasture intake was estimated to be equal to $600 \mathrm{~g}$ of dry matter based on animal energy requirements. Milk was collected individually for each animal at the morning milking, and the bulk milk of each group was used for producing the experimental fermented milk. Bulk milk samples of the HCsM and LCsM groups were analyzed for fat, proteins, and lactose using a Milkoscan 6000 instrument (Foss Electric, Hillerød, Denmark).

\subsection{Lactobacillus Paracasei FS109 Strain Probiotic Selection}

To be used as culture starter to produce the experimental fermented milk, autochthonous L. paracasei strain, namely L. paracasei FS109, already characterized in a previous work [15], was further tested for adhesion ability and immunomodulation effect. The adenocarcinoma cell lines HT-29 and Caco- 2 cells were used to determine the adhesion ability of the Lactobacillus strains, as previously described [23]. Briefly, cells were seeded $(1 \times 105$ cells per well $)$ in 12 -well tissue culture plates and cultured in Dulbecco's modified Eagle medium (DMEM) supplemented with $4 \mathrm{mM} \mathrm{L-glutamine,} 100 \mathrm{U}$ $\mathrm{mL}-1$ penicillin, $100 \mu \mathrm{g} / \mathrm{mL}$ streptomycin, and 10 or $15 \%(v / v)$ fetal bovine serum (FBS) for HT-29 or Caco-2, respectively. Cells were incubated $\left(37^{\circ} \mathrm{C}, 5 \% \mathrm{CO}_{2}\right)$ for either 3 days (HT-29) or 5 days (Caco-2). Overnight cultures of Lactobacillus strains (8-9 $\log$ CFU/mL) were washed with PBS (pH 7.4) and re-suspended in the cell-line medium, without antibiotics and FBS, to achieve a final concentration of $108 \mathrm{CFU} \mathrm{mL}-1$. After medium removal, cell monolayers were also washed twice, and $1 \mathrm{~mL}$ of the Lactobacillus suspensions was added. Adhesion experiments were carried out for $2 \mathrm{~h}$ at $37^{\circ} \mathrm{C}, 5 \% \mathrm{CO}_{2}$. The bacterial suspension was then aspirated, and cell monolayers were washed twice with PBS and detached using a trypsin solution $(0.25 \% w / v)$. Bacterial enumeration was determined at 0 (starting time) and $\mathrm{t} 2$ (after $2 \mathrm{~h}$ ) using appropriate dilutions plated on MRS agar medium and incubated at $37^{\circ} \mathrm{C}$ for $48 \mathrm{~h}$.

Immunomodulation was tested according to Zoumpopoulou et al. [21]. A relative expression of IL10, inducible nitric oxide synthase (iNOS), and COX2 genes was calculated using the $2-\Delta \Delta \mathrm{Ct}$ method, and glyceraldehyde-3-phosphate dehydrogenase (GAPDH) was used as the reference gene. Sequences of primers used are presented in Table 1.

Table 1. Sequences of primers used in the immunomodulation experiment.

\begin{tabular}{cc}
\hline Primer & Sequence \\
\hline IL10 $(\mathrm{F})$ & CACCCACTTCCCAGGCAACC \\
IL10 $(\mathrm{R})$ & TCTCAGACAAGGCTTGGCAACC \\
iNOS $(\mathrm{F})$ & CCCAGCCTCAAGTCTTATTTCCTC \\
iNOS $(\mathrm{R})$ & GCACTCAGCAGCAAGTTCCATC \\
COX2 $(\mathrm{F})$ & CCTGTGCCTGATGATTGC \\
COX2 $(\mathrm{R})$ & CTGATGCGTGAAGTGCTG \\
GAPDH $(\mathrm{F})$ & GAGTCCACTGGCGTCTTC \\
GAPDH $(\mathrm{R})$ & GCATTGCTGATGATCTTGAGG \\
\hline
\end{tabular}

\subsection{Experimental Fermented Milks Production from Different Genotypes}

The performance of this Lactobacillus strain has been compared to L. paracasei CF4, isolated from Casizolu cheese [24] and to L. paracasei ATCC $393^{\mathrm{T}}$ reference strain.

Strains were subcultured twice in MRS (Oxoid, Milan, Italy), and incubated at $30{ }^{\circ} \mathrm{C}$ for $12 \mathrm{~h}$. Before fermented milk production, strains were grown separately in sterile goat milk at $30^{\circ} \mathrm{C}$ until they reached approximately $6 \log \mathrm{CFU} / \mathrm{mL}$.

For the production of experimental fermented milks, $45 \mathrm{~L}$ of milk from each goat group were heated at $90^{\circ} \mathrm{C}$ for $10 \mathrm{~s}$, then cooled down to $30^{\circ} \mathrm{C}$ and divided in three batches: Batch 1 was inoculated with L. paracasei FS109; batch 2 with L. paracasei CF4; and batch 3 with L. paracasei ATCC $393^{\mathrm{T}}$. In all 
cases, an inoculum of $1 \%(w / v)$ was used. The inoculated batches were incubated for $24 \mathrm{~h}$ at $30{ }^{\circ} \mathrm{C}$. Afterward, the products were cooled and kept at $4{ }^{\circ} \mathrm{C}$ for 30 days.

\subsection{Lactobacillus Strains viable Counts and Physicochemical Parameters Determination}

For microbiological analysis, all samples (10 g) were carefully homogenized in $90 \mathrm{~mL}$ sterile Ringer's solution for $2 \mathrm{~min}$ in a Stomacher Lab Blender 80 (PBI, Milan, Italy). Aliquots of $1 \mathrm{~mL}$ were 10-fold diluted in Ringer's solution and inoculated on MRS agar to quantify lactobacilli. Plates were incubated under anaerobiosis (Anaerobic System Anaerogen, Oxoid) at $30{ }^{\circ} \mathrm{C}$ for $48 \mathrm{~h}$. pH value was determined with a pH-meter (Crison Instruments SA, Barcelona, Spain). Acidity determination was carried out in $10 \mathrm{~mL}$ of fermented milk titrated with $0.1 \mathrm{~N} \mathrm{NaOH}$, with phenolphthalein as an indicator and expressed as a percentage of lactic acid. All samples at 0,3,6, 9, and $24 \mathrm{~h}$ of incubation were collected and analyzed immediately. The same microbiological and physicochemical parameters were evaluated at 15 and 30 days during storage at $4{ }^{\circ} \mathrm{C}$. All analyses were carried out in triplicate in fermented milk samples from each batch $(n=3)$.

\subsection{Statistical Analysis}

Mean values of microbiological and physicochemical data from different milk genotypes, various L. paracasei strains, and storage time of fermented milk were compared using the Student's T test, and differences were considered statistically significant at $p<0.05$. Statistical analysis was performed using MINITAB $^{\circledR}$ software (Version 16.1.0, Minitab, State College, PA, USA).

\section{Results}

\subsection{Milk Composition}

The average milk yield was higher in high compared to low goats ( 2610 vs. $2129 \mathrm{~g} /$ day). Overall, the average of the milk fat, protein, and lactose content obtained was $3.19 \%, 3.21 \%$, and $4.41 \%$ for the HCsM and $3.18 \%, 3.24 \%$, and $4.31 \%$ for the LCsM bulk milk, respectively.

\subsection{Lactobacillus Paracasei FS103 Strain Probiotic Features}

The L. paracasei strain showed poor adhesion capacity to HT-29 and Caco-2 cells, namely, less than $1 \%$. The cell counts binding to adenocarcinoma cells were estimated at $4.92 \pm 0.12$ and $5.13 \pm 0.01 \mathrm{log}$ CFU/mL (for HT-29 cells) and $5.59 \pm 0.08$ and $5.30 \pm 0.86$ CFU mL ${ }^{-1}$ (for Caco-2 cells), respectively, after $2 \mathrm{~h}$ of incubation. Regarding immunomodulation results (Table 2), the IL10 expression, was numerically higher than control, even if did not reach the level of significant difference $(p>0.05)$. The iNOS expression was significantly $(p<0.05)$ downregulated when THP-1 cells were co-cultured with FS109, while COX2 mRNA level remained unaffected with L. paracasei FS109 $(p>0.05)$.

Table 2. Immunomodulation properties of L. paracasei FS109 strain in human THP-1 cells. after co-culture for $4 \mathrm{~h}$.

\begin{tabular}{cccccc}
\hline & Min & Max & Average & SD & $p$ Value \\
\hline IL10 & 0.96 & 17.31 & 6.83 & 6.69 & $p>0.05$ \\
COX2 & 0.79 & 1.49 & 1.23 & 0.31 & $p>0.05$ \\
iNOS & 0.56 & 0.96 & 0.67 & 0.15 & $p<0.05$ \\
Control & 1 & 1 & 1 & 0 &
\end{tabular}

IL10, interleukin 10; COX2, cyclooxygenase-2; iNOS inducible nitric oxide synthase; SD, standard deviation; significant differences $(p<0.05)$ were considered in comparison to the untreated control. 


\subsection{Experimental Fermented Milks from Different Genotypes}

\subsection{1. $\mathrm{pH}$ and Titratable Acidity Values}

The genetic polymorphisms in CSN1S1 did not affect $\mathrm{pH}$ (Table 3) and titratable acidity (Table 4) values in both types of goat milk inoculated with the three different $L$. paracasei strains, apart from a difference after $24 \mathrm{~h}$ of fermentation with strain ATCC $393^{\mathrm{T}}$. More precisely, the $\mathrm{pH}$ was lower in the LCsM sample than in the HCsM one. Moreover, higher acidifying activity was obtained for L. paracasei FS109 compared to L. paracasei CF4 and ATCC 393T strains as at $24 \mathrm{~h}$ of fermentation, the $\mathrm{pH}$ value decreased to 4.41 and 3.93 for HCsM and LCsM milk, respectively $(p<0.05)$. At the same incubation time, both HCsM and LCsM milk fermented with L. paracasei FS109 showed a higher value of lactic acid percentage $(p<0.05)$ than those determined in the fermented with the other two Lactobacillus strains. Overall, for each L. paracasei strain tested, the evolution of $\mathrm{pH}$ and lactic acid (Tables 3 and 4 ) over time did not show any difference between high and low genotype fermented milks $(p>0.05)$, except for the L. paracasei ATCC 393T, where $\mathrm{pH}$ at the end of fermentation was lower in LCsM.

Greater acidifying activity ( $\mathrm{pH}$ and titratable acidity) of L. paracasei FS109 was observed throughout the storage period. At $5{ }^{\circ} \mathrm{C}$, $\mathrm{pH}$ values further decreased while lactic acid percentage increased in both genotype groups even if it did not reach the level of significance $(p>0.05)$, except for the L. paracasei CF4 and ATCC $393^{\mathrm{T}}$ strains, for which $\mathrm{pH}$ value was higher at 15 and 30 days of storage in both low and high CSN1S1 fermented milk (Tables 3 and 4). 
Table 3. Evolution of $\mathrm{pH}$ values in HCsM and LCsM bulk milk fermented with L. paracasei strains during fermentation time and cold storage.

\begin{tabular}{|c|c|c|c|c|c|c|c|c|c|c|c|c|c|c|c|c|c|c|c|c|c|c|c|c|c|c|c|c|}
\hline \multirow[t]{3}{*}{ Strain } & \multicolumn{20}{|c|}{ Fermentation Time (h) } & \multicolumn{8}{|c|}{ Cold Storage (Day) } \\
\hline & \multicolumn{4}{|c|}{0} & \multicolumn{4}{|c|}{3} & \multicolumn{4}{|c|}{6} & \multicolumn{4}{|c|}{9} & \multicolumn{4}{|c|}{24} & \multicolumn{4}{|c|}{15} & \multicolumn{4}{|c|}{30} \\
\hline & $\mathrm{HCs}$ & & LCs & & $\mathrm{HCs}$ & & LCsM & & $\mathrm{HCs}$ & & $\mathrm{LCs}$ & & $\mathrm{HCs}$ & & LCsI & & $\mathrm{HCsl}$ & & LCs. & & $\mathrm{HCsl}$ & & LCsI & & $\mathrm{HCs}$ & & LCsI & \\
\hline FS109 & $6.63^{\mathrm{aA}}$ & 0.05 & $6.46^{\mathrm{aA}}$ & 0.1 & $6.88^{\mathrm{aA}}$ & 0.17 & $6.60^{\mathrm{aA}}$ & 0.11 & $6.44^{\mathrm{aA}}$ & 0.2 & $6.60 \mathrm{aA}$ & 0.19 & $6.15^{\mathrm{aA}}$ & 0.15 & $6.10^{\mathrm{aA}}$ & 0.27 & $4.41^{\mathrm{aA}}$ & 0.17 & $3.93^{\mathrm{aA}}$ & 0.31 & $3.85^{\mathrm{aA}}$ & 0.12 & $3.73 \mathrm{aA}$ & 0.12 & $3.79 \mathrm{aA}$ & 0.2 & $3.62^{\mathrm{aA}}$ & 0.13 \\
\hline CF4 & $6.67 \mathrm{aA}$ & 0.23 & $6.53 \mathrm{aA}$ & 0.16 & $6.95 \mathrm{aA}$ & 0.07 & $6.78^{\mathrm{aA}}$ & 0.16 & $6.68^{\mathrm{aA}}$ & 0.13 & $6.82 \mathrm{aA}$ & 0.17 & $6.50 \mathrm{aB}$ & 0.12 & $6.33 \mathrm{aA}$ & 0.07 & $6.63 \mathrm{aC}$ & 0.06 & $6.23^{\mathrm{aC}}$ & 0.14 & $4.00^{\mathrm{aA}}$ & 0.23 & $4.18^{\mathrm{aB}}$ & 0.21 & $4.07 \mathrm{aB}$ & 0.11 & $4.13^{\mathrm{aB}}$ & 0.10 \\
\hline $393^{\mathrm{T}}$ & $6.61 \mathrm{aA}$ & 0.15 & $6.5^{\mathrm{aA}}$ & 0.2 & $6.90^{\mathrm{aA}}$ & 0.16 & $6.75^{\mathrm{aA}}$ & 0.12 & $6.54^{\mathrm{aA}}$ & 0.07 & $6.67 \mathrm{aA}$ & 0.16 & $6.45 \mathrm{aB}$ & 0.06 & $6.35^{\mathrm{aA}}$ & 0.19 & $6.28^{\mathrm{bB}}$ & 0.06 & $5.94^{\mathrm{aB}}$ & 0.11 & 5.42 ав & 0.04 & $5.31 \mathrm{aC}$ & 0.16 & $5.07 \mathrm{aC}$ & 0.16 & $5.36^{\mathrm{bC}}$ & 0.06 \\
\hline
\end{tabular}

Table 4. Evolution of titratable acidity (\% lactic acid) of HCsM and LCsM bulk milk fermented with L. paracasei strains during fermentation time and cold storage.

\begin{tabular}{|c|c|c|c|c|c|c|c|c|c|c|c|c|c|c|c|c|c|c|c|c|c|c|c|c|c|c|c|c|}
\hline \multirow[t]{3}{*}{ Strain } & \multicolumn{20}{|c|}{ Fermentation Time (h) } & \multicolumn{8}{|c|}{ Cold Storage (Day) } \\
\hline & \multicolumn{4}{|c|}{0} & \multicolumn{4}{|c|}{3} & \multicolumn{4}{|c|}{6} & \multicolumn{4}{|c|}{9} & \multicolumn{4}{|c|}{24} & \multicolumn{4}{|c|}{15} & \multicolumn{4}{|c|}{30} \\
\hline & \multicolumn{2}{|c|}{ HCsM } & \multicolumn{2}{|c|}{ LCsM } & \multicolumn{2}{|c|}{$\mathrm{HCsM}$} & \multicolumn{2}{|c|}{ LCsM } & \multicolumn{2}{|c|}{ HCsM } & \multicolumn{2}{|c|}{ LCsM } & \multicolumn{2}{|c|}{ HCsM } & \multicolumn{2}{|c|}{ LCsM } & \multicolumn{2}{|c|}{ HCsM } & \multicolumn{2}{|c|}{ LCsM } & \multicolumn{2}{|c|}{ HCsM } & \multicolumn{2}{|c|}{ LCsM } & \multicolumn{2}{|c|}{ HCsM } & \multicolumn{2}{|c|}{ LCsM } \\
\hline FS109 & $0.21 \mathrm{aA}$ & 0.01 & $0.21^{\mathrm{aA}}$ & 0.03 & $0.25 \mathrm{aA}$ & 0.01 & $0.22 \mathrm{aA}$ & 0.05 & $0.26^{\mathrm{aA}}$ & 0.03 & $0.25 \mathrm{aA}$ & 0.01 & $0.30 \mathrm{aA}$ & 0.09 & 0.31 aA & 0.07 & $0.97 \mathrm{aB}$ & 0.13 & $0.90 \mathrm{aB}$ & 0.09 & $1.13 \mathrm{aC}$ & 0.11 & $1.20 \mathrm{aC}$ & 0.18 & $1.37 \mathrm{aB}$ & 0.32 & $1.43^{\mathrm{aB}}$ & 0.13 \\
\hline CF4 & $0.19 \mathrm{aA}$ & 0.01 & $0.20 \mathrm{aA}$ & 0.02 & $0.21^{\mathrm{aA}}$ & 0.03 & $0.20 \mathrm{aA}$ & 0.03 & $0.21 \mathrm{aA}$ & 0.02 & $0.23 \mathrm{aA}$ & 0.10 & $0.244^{\mathrm{aA}}$ & 0.02 & $0.23 \mathrm{aA}$ & 0.02 & $0.22 \mathrm{aA}$ & 0.01 & $0.21 \mathrm{aA}$ & 0.08 & $0.33 \mathrm{aA}$ & 0.08 & $0.28 \mathrm{aA}$ & 0.01 & $0.70^{\mathrm{aA}}$ & 0.11 & $0.73 \mathrm{aA}$ & 0.33 \\
\hline $393^{\mathrm{T}}$ & $0.18 \mathrm{aA}$ & 0.02 & $0.18^{\mathrm{aA}}$ & 0.02 & $0.21^{\mathrm{aA}}$ & 0.02 & $0.22 \mathrm{aA}$ & 0.03 & $0.23 \mathrm{aA}$ & 0.01 & $0.21 \mathrm{aA}$ & 0.02 & $0.24 \mathrm{aA}$ & 0.03 & $0.23 \mathrm{aA}$ & 0.02 & $0.25 \mathrm{aA}$ & 0.08 & $0.28 \mathrm{aA}$ & 0.02 & $0.50^{\mathrm{aB}}$ & 0.03 & $0.52 \mathrm{aB}$ & 0.21 & $0.67 \mathrm{aA}$ & 0.17 & $0.58 \mathrm{aA}$ & 0.05 \\
\hline
\end{tabular}




\subsubsection{Viable Count Lactobacillus Paracasei Strains}

Microbial analysis (Table 5) showed that in the first $6 \mathrm{~h}$ of fermentation, L. paracasei FS109 and ATCC $393^{T}$ strains reached a viable count of $7 \log \mathrm{CFU} / \mathrm{mL}$, while lower count was observed for L. paracasei CF4 (of about $1 \log \mathrm{CFU} / \mathrm{mL}$ ). In this first part of fermentation, any differences in the $L$. paracasei strains counts were revealed between HCsM and LCsM milk, while L. paracasei CF4 at $9 \mathrm{~h}$ and L. paracasei ATCC $393^{\mathrm{T}}$ count at $24 \mathrm{~h}$ were higher $(p<0.05)$ in LCsM than HCsM. However, after $24 \mathrm{~h}$ of fermentation, L. paracasei FS109 count reached a value significantly higher $(>8.5 \log \mathrm{CFU} / \mathrm{mL})$ than the other two strains tested. During the first 15 days of storage, all lactobacilli counts increased about $1 \log$ and remained quite constant until 30 days of storage, evidencing low mortality during incubation at $5{ }^{\circ} \mathrm{C}$. At 15 days and 30 days, the viable counts were higher in HCsM milk fermented with L. paracasei FS109 and L. paracasei CF4 $(p<0.05)$, whilst the opposite behavior was observed for L. paracasei ATCC $393^{\mathrm{T}}$. These results suggest that the genetic polymorphisms in CSN1S1 did not affect the growth of lactobacilli during fermentation and their viability during cold storage. However, it is interesting to underline that $L$. paracasei FS109 counts were always higher than those of the other two lactobacilli tested and that the high number $(>9 \log \mathrm{CFU} / \mathrm{mL}$ ) at 30 days of cold storage has been detained. 
Table 5. Growth kinetic $(\log \mathrm{CFU} / \mathrm{mL})$ of L. paracasei strains in HCsM and LCsM milk during fermentation and cold storage.

\begin{tabular}{|c|c|c|c|c|c|c|c|c|c|c|c|c|c|c|c|c|c|c|c|c|c|c|c|c|c|c|c|c|}
\hline \multirow[t]{3}{*}{ Strain } & \multicolumn{20}{|c|}{ Fermentation Time (h) } & \multicolumn{8}{|c|}{ Cold Storage (Day) } \\
\hline & \multicolumn{4}{|c|}{0} & \multicolumn{4}{|c|}{3} & \multicolumn{4}{|c|}{6} & \multicolumn{4}{|c|}{9} & \multicolumn{4}{|c|}{24} & \multicolumn{4}{|c|}{15} & \multicolumn{4}{|c|}{30} \\
\hline & $\mathrm{HCs}$ & & LCsI & & $\mathrm{HCs}$ & & LCs & & $\mathrm{HCsl}$ & & LCs & & $\mathrm{HCs}$ & & LCsI & & $\mathrm{HCsl}$ & & LCsI & & $\mathrm{HCsl}$ & & LCsI & & $\mathrm{HCsN}$ & & LCsN & \\
\hline FS109 & $5.75 \mathrm{aA}$ & 0.14 & $5.89 \mathrm{aA}$ & 0.09 & $6.54^{\mathrm{aA}}$ & 0.02 & $6.39^{\mathrm{aA}}$ & 0.17 & $7.14^{\mathrm{aB}}$ & 0.02 & $7.08^{\mathrm{aB}}$ & 0.06 & $7.34^{\mathrm{aB}}$ & 0.36 & $7.43^{\mathrm{aB}}$ & 0.17 & $8.57 \mathrm{aC}$ & 0.06 & $8.78 \mathrm{aC}$ & 0.07 & $9.48 \mathrm{aC}$ & 0.31 & $9.33^{\mathrm{aB}}$ & 0.20 & $9.30 \mathrm{bC}$ & 0.08 & $9.06 \mathrm{aB}$ & 0.10 \\
\hline $\mathrm{CF} 4$ & $5.80 \mathrm{aA}$ & 0.12 & $5.79 \mathrm{aA}$ & 0.13 & $6.19 \mathrm{aB}$ & 0.16 & $6.07^{\mathrm{aA}}$ & 0.10 & $6.46^{\mathrm{aA}}$ & 0.11 & $6.40^{\mathrm{aA}}$ & 0.05 & $6.68^{\mathrm{aA}}$ & 0.07 & $7.35^{\mathrm{bB}}$ & 0.19 & 7.93 aB & 0.19 & $7.85^{\mathrm{aA}}$ & 0.06 & $8.55^{\mathrm{aB}}$ & 0.05 & $8.29 \mathrm{aA}$ & 0.76 & $8.95^{\mathrm{bB}}$ & 0.12 & $8.44^{\mathrm{aA}}$ & 0.01 \\
\hline $393^{\mathrm{T}}$ & $5.93 \mathrm{aA}$ & 0.06 & $5.97 \mathrm{aA}$ & 0.15 & $6.58^{\mathrm{bA}}$ & 0.10 & $6.24^{\mathrm{aA}}$ & 0.12 & $7.06^{a B}$ & 0.20 & $7.18^{\mathrm{aB}}$ & 0.26 & $6.98^{\mathrm{aB}}$ & 0.01 & $6.95 \mathrm{aA}$ & 0.02 & $7.65^{\mathrm{aA}}$ & 0.06 & $7.98^{\mathrm{bA}}$ & 0.07 & $8.30 \mathrm{aA}$ & 0.04 & $8.24^{\mathrm{aA}}$ & 0.08 & $8.22 \mathrm{aA}$ & 0.05 & $8.46^{\mathrm{bA}}$ & 0.02 \\
\hline
\end{tabular}




\section{Discussion}

The composition of bulk milk did not evidence any difference in milk protein content in the group with high compared with low CSN1S1 genotype. By contrast, previous research reported a higher protein content in the milk of animals with a strong rather than weak genotype [25,26]. However, the similar content in protein could be partly explained by the lower milk yield of the low group at the sampling date, which may have caused a concentration of protein fraction. The differences in milk yield suggest greater intake of nutrient from goats of high genotype compared to low, during grazing activity. This is supported by previous observations $[27,28]$, where goats with strong alleles evidenced greater intake and a superior diet efficiency than animal with low casein.

Strains of $L$. paracasei are isolated from various ecological niches, such as plant, milk, and animal gut, and are largely applied as starter cultures in the dairy industry. Some L. paracasei strains are highly valued for their probiotic properties being able to improve clinical outcomes [29].

In this study, low adhesion ability to intestinal epithelium cell lines was detected for the L. paracasei FS109 strain, but in some cases, in vitro experiments for adherence ability of strains have limited predictability for the real in vivo situation [30]. Regarding immunomodulation, FS109 strain was capable of decreasing iNOS expression, exhibiting the best antioxidant properties. iNOS produces large amounts of nitric oxide (NO), one of the most important signaling molecules in inflammation [31].

In order to select a starter suitable to fermented milk production, technological evaluation of strain includes the acidifying activity as well as the ability to survive during the storage of the product. Overall, this study revealed that different genetic polymorphisms in CSN1S1 of goat milk fermented by L. paracasei FS109 did not affect both abovementioned technological parameters, whereas significant differences between strains have been found. The selected L. paracasei FS109 showed higher acidifying activity compared to the other lactobacilli strains tested. The low $\mathrm{pH}$ value reached at the end of fermentation is considered optimal, as it makes the substrate unsuitable for the growth of spoilage and/or pathogenic microorganisms [32]. More generally, an adequate acidification during fermented milk production can positively affect the rheological and sensory properties of the final product [33]. Moreover, the high viable count determined at $24 \mathrm{~h}$ of fermentation, independently from milk polymorphisms of CSN1S1, highlights a remarkable adaptability of L. paracasei FS109 to both substrates.

The same strain has also led to a further increase of the acidity level during cold storage, due to post-acidification, which occurs from the continuous production of organic acid by the added starter. Post-acidification can affect the growth and viability of starter and/or probiotic microorganisms and consequently reduce the health benefit of milk fermented product [34]. For instance, in yogurt added with probiotics, L. acidophilus strain counts decreased, maintaining the minimum concentration for a beneficial effect only until 3 weeks of storage, as reported by Damin et al. [35].

In this study, although $\mathrm{pH}$ value of fermented milk further decreases (about 3.7) during storage, a high viable number of L. paracasei FS109 (about $9 \log$ CFU/mL) throughout the 30 days of storage was observed. These data confirmed the results of previous research [15], where the same L. paracasei strain showed a high acid tolerance after $3 \mathrm{~h}$ of incubation in the synthetic medium at $\mathrm{pH} 2.5$.

The ability of L. paracasei FS109 strain to resist acid stress leads us to suppose that it could withstand the acidic conditions of the stomach, the first barrier that a probiotic microorganism must overcome to exert a health effect [36]. In addition, our strains could be a potential in vivo colonizer as suggested by Wang et al. [37] for L. paracasei FM-LP-4, a strain able to resist under the same in vitro conditions ( $\mathrm{pH}$ 2.5 per $3 \mathrm{~h}$ ).

No specific information is available in fermented goat milk, but in cow milk, a strong influence of genetic variant of milk protein was evidenced on the fermentative ability with the yoghurt culture [38], indicating that fermentation tests together with milk proteins genotype could contribute to improving nutritional values of fermented milk and highlight new perspectives in dairy goat production system. 


\section{Conclusions}

An appropriate selection of the type of milk and the culture starter used could be a potential strategy to produce fermented milk with added nutritional value. The present study shows that milk with a low CSN1S1 genotype is suitable to produce fermented milk product. L. paracasei FS109 strain evidenced features to be a beneficial culture starter. Finally, combining the positive characteristics of both CSN1S1 genotype goat milk and a selected L. paracasei strains can be a good strategy for improving the traditional and functional fermented milk market.

Author Contributions: N.P.M. and A.N. conceived the experimental design; G.Z., R.A., I.K., D.S., and L.S. performed strains probiotic characterization; E.T. conceived the probiotic experimental design; A.N. performed the identification of experimental animals, based on their genotype; S.C. performed genotypic characterization of casein variants; N.P.M. and L.S. performed all microbiological analysis; N.P.M. and A.N. drafted the manuscript.

Funding: This research received no external funding.

Conflicts of Interest: The authors declare no conflict of interest.

\section{References}

1. Carroccio, A.; Cavataio, F.; Montalto, G.; D'Amico, D.; Alabrese, L. Intolerance to hydrolysated cow's milk proteins in infants: Characteristics and dietary treatment. Clin. Exp. Allergy. 2000, 18, 1597-1603.

2. Restani, P. Goat milk allergenicity. J. Pediat. Gastroenterol. Nutr. 2004, 39, 323-324. [CrossRef]

3. Chessa, S.; Caroli, A.M. Polimorfismi genetici latto-proteici caprini e ovine ed effetti sulla qualità del latte. Large Anim. Rev. 2014, 4, $23-27$.

4. Martin, P.; Ollivier-Bousquet, M.; Grosclaude, F. Genetic polymorphism of caseins: A tool to investigate casein micelle organization. Int. Dairy J. 1999, 9, 163-171. [CrossRef]

5. Caroli, A.M.; Chiatti, F.; Chessa, S.; Rignanese, D.; Ibeagha-Awemu, E.; Erhardt, G. Characterization of the casein gene complex in West Africa goats and description of a new $\alpha$ S1-casein polymorphism. J. Dairy Sci. 2007, 90, 2989-2996. [CrossRef] [PubMed]

6. Perna, A.; Simonetti, A.; Grassi, G.; Gambacorta, E. Effect of $\alpha$ S1-casein genotype on phenolic compounds and antioxidant activity in goat milk yogurt fortified with Rhus coriaria leaf powder. I. Dairy J. 2013, 31, 65-69. [CrossRef] [PubMed]

7. Skeie, S.B.; Inglingstad, R.A.; Brunborg, L.J.; Eknæs, M. The influence of the deletion in exon 12 of the gene encoding $\alpha$ s1-casein (CSN1S1) in the milk of the Norwegian dairy goat breed on milk coagulation properties and cheese quality. Small Rum. Res. 2014, 122, 50-58. [CrossRef]

8. Bevilacqua, C.; Martin, P.; Candalh, C.; Fauquant, J.; Piot, M.; Roucayrol, A.M.; Pilla, F.; Heyman, M. Goats' milk of defective alpha(s1)-casein genotype decreases intestinal and systemic sensitization to beta-lactoglobulin in guinea pigs. J. Dairy Res. 2001, 68, 217-227. [CrossRef]

9. Albenzio, M.; Campanozzi, A.; D'Apolito, M.; Santillo, A.; Pettoello Mantovani, M.; Sevi, A. Differences in protein fraction from goat and cow milk and their role on cytokine production in children with cow's milk protein allergy. Small Rum. Res. 2012, 105, 202-205. [CrossRef]

10. Sanna, M.G.; Mangia, N.P.; Garau, G.; Murgia, M.A.; Massa, T.; Franco, A.; Deiana, P. Selection of folate-producing lactic acid bacteria for improving fermented goat milk. Italian J. Food Sci. 2005, 17, 143-154.

11. Minervini, F.M.; Bilancia, T.; Siragusa, S.; Gobbetti, M.; Caponio, F. Fermented goats' milk produced with selected multiple starters as a potentially functional food. Food Microbiol. 2009, 26, 559-564. [CrossRef] [PubMed]

12. Tamine, A.Y.; Wszolek, M.; Bozanic, R.; Ozer, B. Popular ovine and caprine fermented milks. Small Rum. Res. 2011, 101, 2-16. [CrossRef]

13. Mangia, N.P.; Murgia, M.A.; Fancello, F.; Nudda, A.; Deiana, P. Influence of Myrtle Juice and Syrup on Microbiological, Physicochemical and Sensory Features of Goat's Milk Yogurt Made with Indigenous Starter Culture. J. Microb. Biochem. Technol. 2014, 6, 370-374. [CrossRef]

14. Vinderola, C.G.; Mocchiutti, P.; Reinheimer, J.A. Interactions among lactic acid starter and probiotic bacteria used for fermented dairy products. J. Dairy Sci. 2002, 85, 721-729. [CrossRef] 
15. Mangia, N.P.; Saliba, L.; Deiana, P. Functional and safety characterization of autochthonous Lactobacillus paracasei FS103 isolated from sheep cheese and its survival in sheep and cow fermented milk during cold storage. Ann. Microbiol. 2019, 69, 161-170. [CrossRef]

16. Candela, M.; Perna, F.; Carnevali, P.; Vitali, B.; Ciati, R.; Gionchetti, P.; Rizzello, F.; Campieri, M.; Brigidi, P. Interaction of probiotic Lactobacillus and Bifidobacterium strains with human intestinal epithelial cells, adhesion properties, competition against enteropathogens and modulation of IL-8 production. Int. J. Food Microbiol. 2008, 125, 286-292. [CrossRef] [PubMed]

17. Bengoa, A.A.; Zavala, L.; Carasi, P.; Trejoc, S.A.; Bronsoms, S.; Serradell, M.L.A.; Garrote, G.L.; Abraham, A.G. Simulated gastrointestinal conditions increase adhesion ability of Lactobacillus paracasei strains isolated from kefir to Caco-2 cells and mucin. Food Res. Int. 2018, 103, 462-467. [CrossRef]

18. de Moreno de Leblanc, A.; Del Carmen, S.; Zurita-Turk, M.; Santos Rocha, C.; van de Guchte, M.; Azevedo, V.; Miyoshi, A.; Leblanc, J.G. Importance of IL-10 modulation by probiotic microorganisms in gastrointestinal inflammatory diseases. ISRN Gastroenterol. 2011, 892971. [CrossRef]

19. Fioramonti, J.; Theodorou, V.; Bueno, L. Probiotics: What are they? What are their effects on gut physiology? Best Pract. Res. Clin. Gastroenterol. 2003, 17, 711-724. [CrossRef]

20. Brzozowski, T.; Konturek, P.C.; Mierzwa, M.; Drozdowicz, D.; Bielanski, W.; Kwiecien, S.; Konturek, S.J.; Stachura, J.; Pawlik, W.W.; Hahn, E.G. Effect of probiotics and triple eradication therapy on the cyclooxygenase (COX)-2 expression, apoptosis, and functional gastric mucosal impairment in Helicobacter pylori-infected Mongolian gerbils. Helicobacter. 2006, 11, 10-20. [CrossRef]

21. Peran, L.; Camuesco, D.; Comalada, M.; Bailon, E.; Henriksson, A.; Xaus, J.; Zarzuelo, A.; Galvez, J. A comparative study of the preventative effects exerted by three probiotics, Bifidobacterium lactis, Lactobacillus casei and Lactobacillus acidophilus, in the TNBS model of rat colitis. J. Appl. Microbiol. 2007, 103, 836-844. [CrossRef] [PubMed]

22. Caboni, P.; Murgia, A.; Porcu, A.; Demuru, M.; Pulina, G.; Nudda, A. Gas chromatography-mass spectrometry metabolomics of goat milk with different polymorphism at the $\alpha$ S1-casein genotype locus. J. Dairy Sci. 2016, 99, 6046-6051. [CrossRef] [PubMed]

23. Zoumpopoulou, G.; Tzouvanou, A.; Mavrogonatou, E.; Alexandraki, V.; Georgalaki, M.; Anastasiou, R.; Papadelli, M.; Manolopoulou, E.; Kazou, M.; Kletsas, D.; et al. Probiotic Features of Lactic Acid Bacteria Isolated from a Diverse Pool of Traditional Greek Dairy Products Regarding Specific Strain-Host Interactions. Probiotics Antimicrob. Proteins. 2017, 10, 313-322. [CrossRef] [PubMed]

24. Mangia, N.P.; Fancello, F.; Deiana, P. Microbiological characterization using combined culture dependent and independent approaches of Casizolu pasta filata cheese. J. Appl. Microbiol. 2016, 120, 329-345. [CrossRef]

25. Chilliard, Y.; Rouel, J.; Leroux, C. Goats alpha-s1-casein genotype influences its milk fatty acid composition and delta-9 desaturationratios. Anim. Feed Sci. Tech. 2006, 131, 474-487. [CrossRef]

26. Avondo, M.; Pennisi, P.; Lanza, M.; Pagano, R.I.; Valenti, B.; Di Gregorio, P.; De Angelis, A.; Giorgio, D.; Di Trana, A. Effect of the $\alpha$ s1-casein genotype and its interaction with diet degradability on milk production, milk quality, metabolic and endocrinal response of Girgentana goats. Small Rum. Res. 2015, 123, 136-141. [CrossRef]

27. Schmidely, P.; Meschy, F.; Tessier, J.; Sauvant, D. Lactation response and nitrogen, calcium and phosphorus utilization of dairy goats differing by the genotype for $\alpha$ s1-casein in milk, and fed diets vaying in crude protein concentration. J. Dairy Sci. 2002, 85, 2299-2307. [CrossRef]

28. de la Torre, G.; Ramos Morales, E.; Serradilla, J.M.; Gil Extremera, F.; Sanz Sampelayo, M.R. Milk production and composition in Malagueña dairy goat. Effect of genotype for synthesis of $\alpha$ s1-casein on milk production and its interaction with dietary protein content. J. Dairy Res. 2009, 76, 137-143. [CrossRef]

29. Jones, R.M. The Use of Lactobacillus casei and Lactobacillus paracasei in Clinical Trials for the Improvement of Human Health. In The Microbiota in Gastrointestinal Pathophysiology; Floch, M., Ringel, Y., Walker, W.A., Eds.; Elsevier: Amsterdam, The Netherlands, 2017; Chapter 9; pp. 99-108.

30. Sanders, M. Probiotics: Definition, sources, selection, and uses. Clin. Infect. Dis. 2008, 46, 58-61. [CrossRef]

31. Ibiza, S.; Serrador, J.M. The role of nitric oxide in the regulation of adaptive immune responses. Immunología. 2008, 27, 103-117. [CrossRef]

32. Alonso, L.; Cuesta, E.P.; Gilliland, S.E. Production of free conjugated Linoleic acid by Lactobacillus acidophilus and Lactobacillus casei of human intestinal origin. J. Dairy Sci. 2003, 86, 1941-1946. [CrossRef] 
33. Jumah, R.Y.; Abu-Jdayil, B.; Shaker, R.R. Effect of type and level of starter culture on the rheological properties of set yogurt during gelation process. Int. J. Food Prop. 2001, 4, 531-544. [CrossRef]

34. Shah, N.P.; Ravula, R.R. Influence of water activity on fermentation, organic acids production and viability of yogurt and probiotic bacteria. Aust. J. Dairy Technol. 2000, 55, 127-131.

35. Damin, M.R.; Minowa, E.; Alcantara, M.R.; Oliveira, M. Effect of cold storage on culture viability and some rheological properties of fermented milk prepared with yogurt and probiotic bacteria. J. Texture Studies. 2008, 39, 40-55. [CrossRef]

36. Culligan, E.P.; Hill, C.; Sleator, R.D. Probiotics and gastrointestinal disease: Successes, problems and future prospects. Gut Pathog. 2009, 1, 19. [CrossRef]

37. Wang, Y.; Zhou, J.Z.; Xia, X.D.; Zhao, Y.C.; Shao, W.L. Probiotic potential of Lactobacillus paracasei FM-LP-4 isolated from Xinjiang camel milk yogurt. Int. Dairy J. 2016, 62, 28-34. [CrossRef]

38. Kyselová, J.; Ječmínková, K.; Matějíčková, J.; Hanuš, O.; Kott, T.; Štípková, M.; Krejčová, M. Physiochemical characteristics and fermentation ability of milk from Czech Fleckvieh cows are related to genetic polymorphisms of $\beta$-casein, K-casein, and $\beta$-lactoglobulin. Asian-Australas. J. Anim. Sci. 2019, 32, 14-22. [CrossRef]

(C) 2019 by the authors. Licensee MDPI, Basel, Switzerland. This article is an open access article distributed under the terms and conditions of the Creative Commons Attribution (CC BY) license (http://creativecommons.org/licenses/by/4.0/). 